\title{
STROBILATION IN A MOLLUSC; THE DEVELOPMENT OF ABERRANT STAGES IN CLIO PYRAMIDATA LINNAEUS, 1767 (GASTROPODA, PTEROPODA)
}

\author{
by \\ S. VAN DER SPOEL \\ Institute of Taxonomic Zoology, University of Amsterdam, The Netherlands
}

\begin{abstract}
SUMMARY
The occurrence of aberrant stages in the protandric hermaphrodite Clio pyramidata is considered in relation to the sexual cycle of this species. The anatomy of the juveniles, males and females is shortly discussed especially with regard to their sexual organs. The anatomy of the developing (the normal-complete) and of the growingaberrant stage is briefly reviewed. It is shown that the aberrant stage is formed by strobilation of a normal specimen, probably as a result of less favourable environmental conditions. As the most important conclusions it can be stated that:

1) the aberrant stage described by van der Spoel (1962) is a normal stage in the life cycle;

2) the aberrants are most abundant in the population in the months before the reproductive peaks;

3) the aberrants seem to occur more frequently when environmental conditions become less favourable;

4) the aberrants develop from specimens in the female phase;

5) the aberrants deve'op into ma'e specimens;

6) the aberrants arise by strobilation of a normal specimen;

7) the animal, which gives rise by strobilation to an aberrant, is after strobilation an asexual shell-less specimen;

8) the strobilation points to an evolutionary relation between worms and molluscs.
\end{abstract}

\section{INTRODUCTION}

The biology of Clio pyramidata Linnaeus, 1767, has been discussed recently by me (van der Spoel, 1973) but the phenomenon of the aberrant stage (van der Spoel, 1962) was not considered. The aberrant stage is characterized by a small animal, with very little anatomical differentiation, in a normally fullgrown shell. The development of the aberrant stages needs a complete description, since the place of this stage in the life cycle of the species was never understood.

After my first communication on the aberrant stage (van der Spoel, 1962) no records of this stage by other specialists have been published. This stage is thus either rare or difficult to recognize. Careful examination of pteropod samples, however, learned that the aberrant stage of Clio pyramidata occurs regularly in small numbers. I have seen only one sample in which they were abundant, taken by Mrs. A. C. PierrotBults, M. Sc. and Mr. R. W. M. van Soest, M. Sc. at $47^{\circ} 31^{\prime} \mathrm{N} 06^{\circ} 59^{\prime} \mathrm{W}$, containing over 50 aberrant specimens. The aberrant stage develops by a process of strobilation comparable to the strobilation in some worms.

The specimens which made it possible to study the place of the aberrant stage in the life cycle of the species, were collected by the Ocean Acre Program 1). In these samples specimens in full aberrant stage were found together with specimens showing the transition to this stage. In this paper the anatomy of juveniles, males, hermaphrodites, females and aberrant stage will be compared briefly and the development of the latter will be explained.

\section{ACKNOWLEDGEMENTS}

The author wishes to express his sincere thanks to Dr. C. F. E. Roper from the United States National Museum, Washington (D.C.), for providing the material of the Ocean Acre Program. Mr. A. F. de Fluiter made the histological slides and Mr. L. A. van der Laan made the photomicrographs. For their assistance the author is very grateful.

1) supported by funds of the U.S. Navy 
Table I. Material of Clio pyramidata studied.

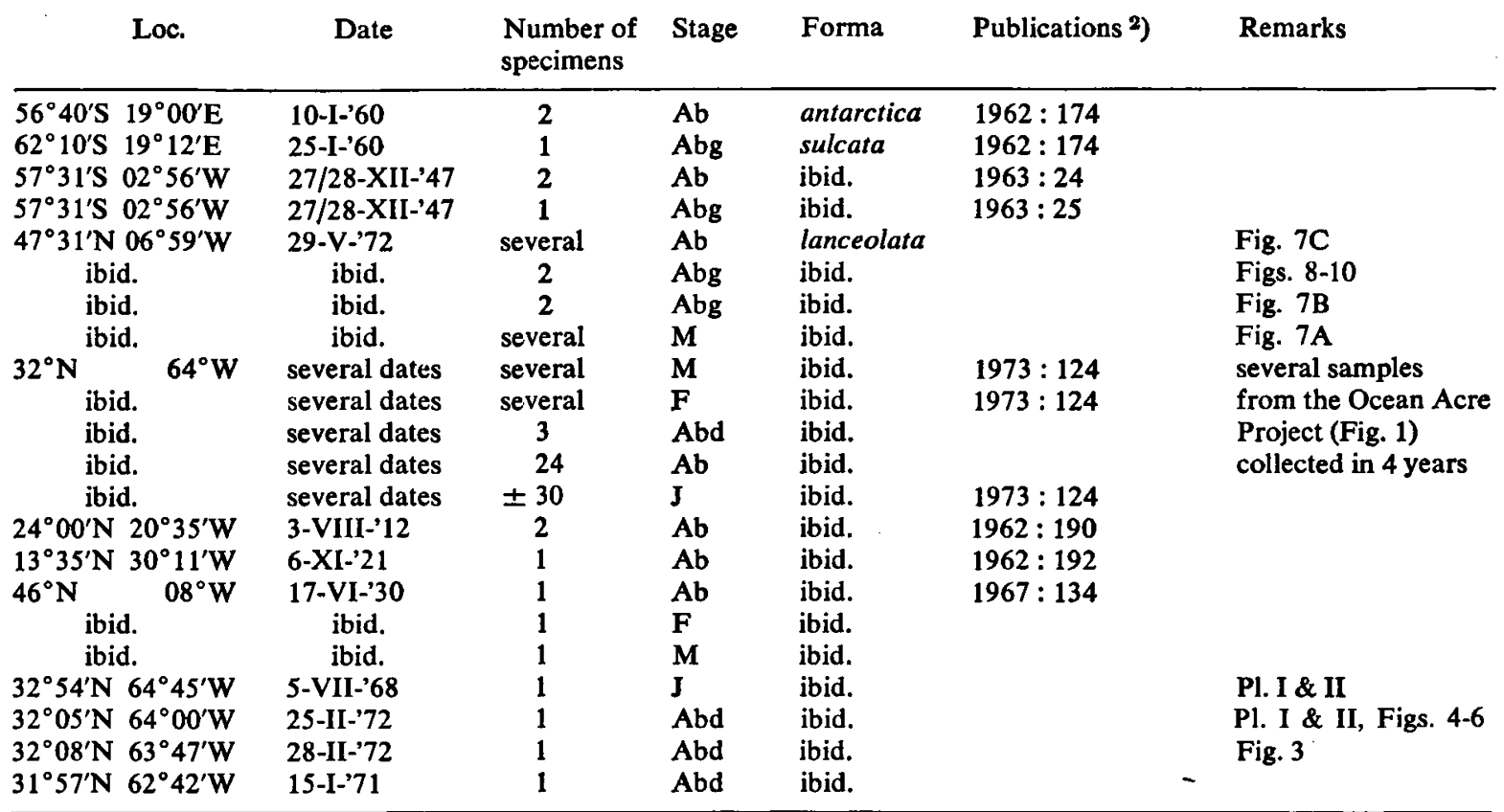

2) this column refers, with year and page, to papers by the present author dealing with the specimens listed.

\section{MATERIAL AND TECHNICS}

The studies on aberrant stages and the comparison with normal specimens were based on the material listed in table I. In this table the following abbreviations are used:

$\mathrm{Ab}=$ aberrant stage; $\mathrm{Abd}=$ developing aberrant stage (strobilation); $\mathrm{Abg}=$ aberrant stage growing out; $\mathrm{F}=$ female; $\mathrm{M}=$ male; $\mathrm{J}=$ juvenile.

All specimens except for some of the aber- rant stages and most of the specimens collected at $47^{\circ} 31^{\prime} \mathrm{N} 06^{\circ} 59^{\prime} \mathrm{W}$ were studied histologically. From the 24 aberrants collected by the Ocean Acre Program, 16 specimens have been studied histologically. The serial histological sections, 5 $\mu$ thick, were stained with Haematoxylin-Eosin. The soft parts were delivered from their shells by pulling the body with a pair of tweezers in anterior direction. Only some very fragile specimens and the specimen showing strobilation were delivered by decalcification.

$\begin{array}{ll}\text { AG } & \text { Accessory sexual gland } \\ \text { BS } & \text { Bursa seminis } \\ \text { BB } & \text { Mucus body } \\ \text { BM } & \text { Basal membrane } \\ \text { CB } & \text { Cytoplasm bands } \\ \text { CE } & \text { Ciliated cells } \\ \text { CF } & \text { Circular muscles } \\ \text { CJ } & \text { Cell wall } \\ \text { CNS } & \text { Central nervous system } \\ \text { CO } & \text { Connective tissue } \\ \text { DL } & \text { Mucus in liver cells } \\ \text { EO } & \text { Esophagus } \\ \text { ES } & \text { Epithelial shield } \\ \text { FS } & \text { Female sexual products } \\ \text { GS } & \text { Germinating sperm } \\ \text { GD } & \text { Gonoduct } \\ \text { GE } & \text { Germinal epithelium } \\ \text { GI } & \text { Gizzard } \\ \text { GO } & \text { Gonad } \\ \text { G1; } & \text { G2; G3 Folds in AG }\end{array}$

$\begin{array}{ll}\text { ABBREVIATIONS USED IN THE FIGUR } \\ \text { HE } & \text { Heart } \\ \text { IC } & \text { Interstitial cells } \\ \text { IN } & \text { Intestine } \\ \text { KI } & \text { Kidney } \\ \text { LI } & \text { Liver } \\ \text { LC } & \text { Liver cells } \\ \text { LD } & \text { Liver duct } \\ \text { LE } & \text { Liver epithelium } \\ \text { LL } & \text { Lateral lips } \\ \text { LT } & \text { Left tentacle } \\ \text { MA } & \text { Mantle } \\ \text { MG } & \text { Mantle corner gland } \\ \text { ML } & \text { Median lip } \\ \text { MO } & \text { Mouth } \\ \text { MV } & \text { Muscle cells } \\ \text { MX } & \text { Shell matrix } \\ \text { NO } & \text { Nucleolis } \\ \text { NU } & \text { Nucleus } \\ \text { OV } & \text { Ovum } \\ \text { PA } & \text { Pallial gland }\end{array}$

$\begin{array}{ll}\text { PE } & \text { Penis } \\ \text { PF } & \text { Posterior footlobe } \\ \text { PU } & \text { Penial sac } \\ \text { RM } & \text { Columellar muscle } \\ \text { RN } & \text { Normal reserve cells } \\ \text { RS } & \text { Receptaculum seminis } \\ \text { RT } & \text { Right tentacle } \\ \text { RV } & \text { Young liver cells of aberrants } \\ \text { S } & \text { Statocysts } \\ \text { SH } & \text { Shell } \\ \text { SI } & \text { Sperm } \\ \text { SS } & \text { Sustentacular cells of Sertoli } \\ \text { SPT } & \text { Sperm tails } \\ \text { ST } & \text { Stomach } \\ \text { WI } & \text { Wings } \\ \text { WM } & \text { Wing muscle } \\ \text { XA, XB, XC, XD, XE, XF, } \\ \text { XH } & \text { Tubes in the aberrant stage } \\ \text { YC } & \text { Young columellar muscle } \\ \text { YL } & \text { Young liver cells }\end{array}$




\section{SEXUAL CYCLE}

Clio pyramidata is a protandric hermaphrodite. The anatomical development of the juveniles passes directly into that of the male phase. After the male phase a hermaphroditic stage occurs in which sperm and eggs are usually present together in the gonad, a real female phase occurs after the hermaphroditic one. As discussed before (van der Spoel, 1973) in all probability more than one protandric cycle may occur in one and the same animal. The last female phase of the first protandric cycle is expected to change over gradually into the male phase of the second cycle when two cycles take place. Sperm transfer may occur between animals which are both in the male stage. In the Bermuda area, where most of the material was collected on which the life cycle of this species is reconstructed, a reproduction peak occurs in spring and a smaller one in autumn (van der Spoel, 1973). The aberrant stages are found throughout the whole year as can be concluded from material collected by several expeditions. From the material of the Bermuda area, however, it is obvious that the aberrant stages are not found in periods with a high reproduction rate (fig. 1). The skinny stages are

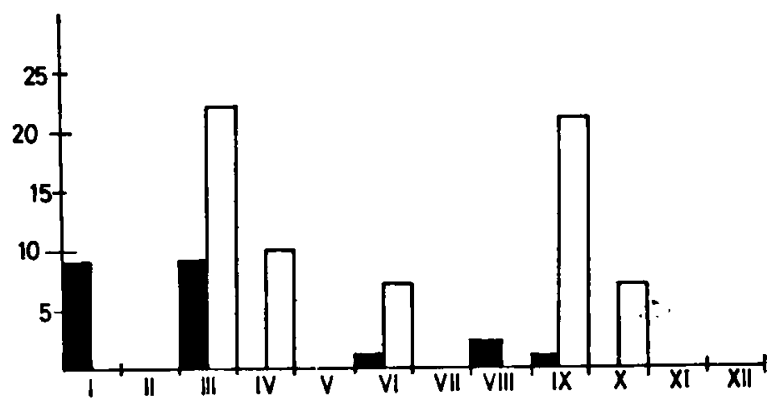

Fig. 1. Number of aberrant stages (black bars) and skinny stages (open bars) on absciss, collected in the different months of the year (roman figures on ordinate) by the Ocean Acre Program.

most frequent in these periods. The skinny stage is described in a pievious paper (van der Spoel, 1967) as a stage following the juvenile stages in which the shell grows more rapid than the body does. Thus a significant positive correlation between the maximum occurrence of skinny stages and the reproductive activity is logical. The aberrant stage does not show such a correlation. The quantities of aberrant stages collected are too small to permit a definite interpretation, but the fol- lowing hypothetical possibilities can be considered:

1) the aberrant stages are rare since they do as a rule not occur in the life cycle of each specimen.

2) The lifetime of aberrants is so short that they are not regularly collected.

3) When aberrants occur they are developing before each reproductive period.

As will be shown below it is most logical to expect that the aberrant develops from a specimen in the female phase. This implicates that the aberrants develop from adult specimens at an age of about half a year, which have hatched during the previous reproductive period.

Some of the aberrants were collected near the surface, others in deeper layers, but they were always collected together with normal, full-grown specimens. As aberrants have no functional locomotory organs, it is tempting to assume that an excessive sinking rate makes the percentage of aberrants in the populations of Clio pyramidata small. But there are no records indicating high concentrations of aberrants in deeper layers of the ocean, on the contrary the highest abundance of this stage is found in the surface layers (based on pooled records of the various cruises and expeditions).

\section{The juvenile stage}

Very young specimens just hatched were not collected by the Ocean Acre Program. In the young specimens at my disposal the sexual organs are represinted by germinal and interstitial cells. For a description of juvenile stages one is referred to van der Spoel (1967: 153).

In pl. II fig. B photomicrographs of five histological sections from a developing young specimen are given. The figures of these sections correspond with the figures of the different planes in text-fig. 2, so that their position can be identified. The gonad (pl. I fig. A) is present and completely composed of germinal cells. The gonoduct is only visible in some of the histological sections and this duct is nowhere completely differentiated. The accessory sexual gland, composed of interstitial cells forms only a rather simple sac-like structure. The penis is still developing as demonstrated by the penial sac composed of interstitial cells in a growing epithelium. The sexual system is thus developing and 


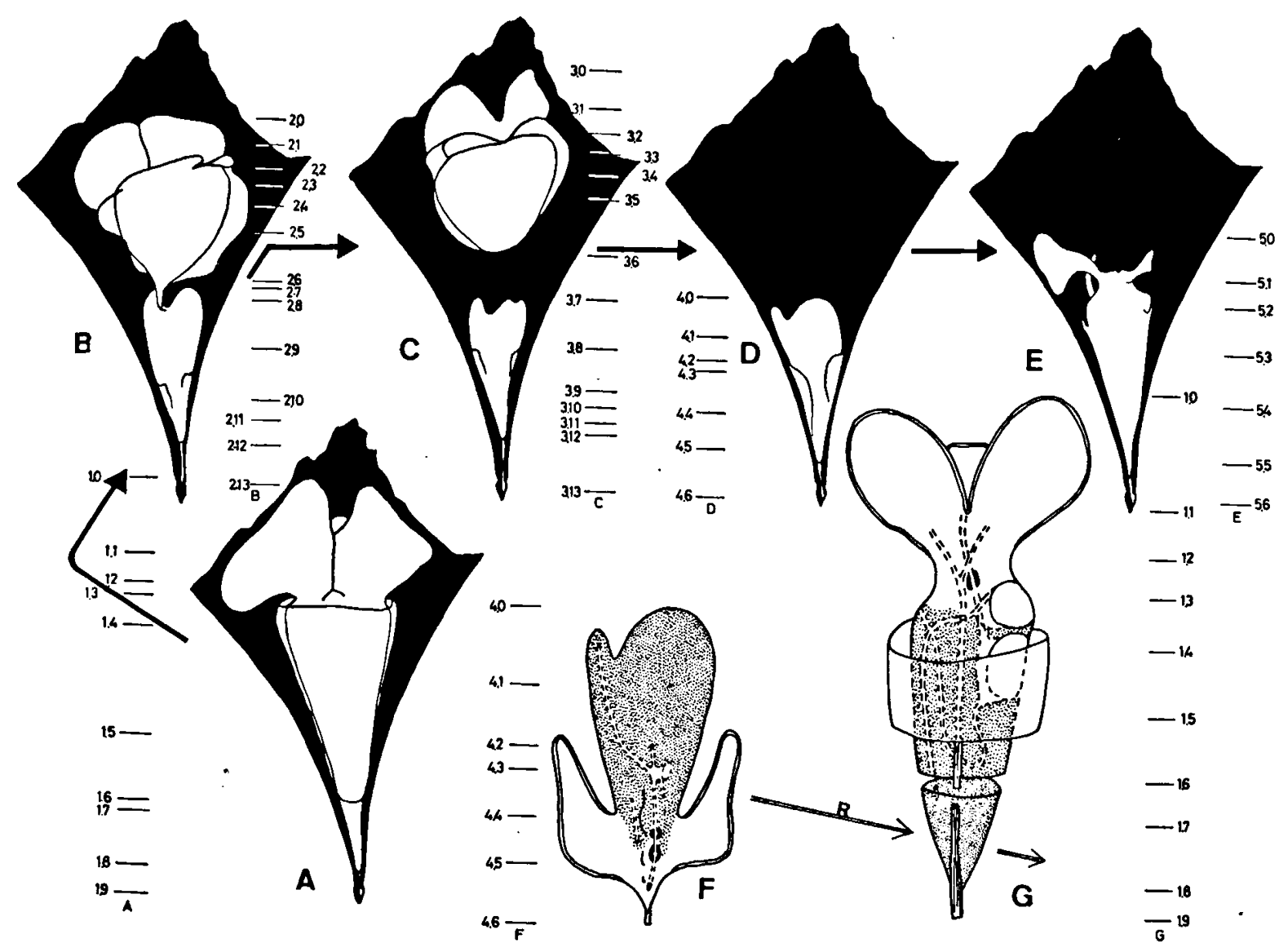

Fig. 2. Diagram showing the life cycle in Clio pyramidata through the aberrant stage. Black arrows indicate the course of development from a normal specimen (A) through strobilation in specimen (B) and separation in specimen (C) to an aberrant (D), which develops again to a nornal specimen (E). Figure $F$ gives the aberrant with its internal organization which "replaces" (indicated by the arrow $\mathbf{R}$ ) the gonad of a normal specimen given in G with its internal organization (the place of strobilation is indicated by an open space). The numerals 1.0 to 5.6 indicate the planes from which the histological sections are provided in plate II.

not yet functional. All other organs are,completely present and functional. In the digestive system food is found, the central nervous system is completely present and the wings are normal in shape and structure, provided with two crossing muscle layers, a lumen and a central muscle. The pallial gland shows some juvenile characters, in the typical relative dimensions of the transversal bands in the shield. The columellar muscle is normally attached to the shell. Though most organs are well developed, they are smaller than those in adult specimens.

It should be noticed that the juvenile specimens are recognizable by their lighter colour, also when in preserved state. The gonad is not yet fully present so that the brownish colour of this part is lacking and the integument pigmentation is usually less intensive than in adults. From several structuies, such as the gonad follicles or the type of germinating cells and the developing penis, it is clear that the first sexual stage must become a male phase.

\section{The male phase}

The external body morphology is closely similar to that in juveniles and females. The body in all formae of this species is more or less pyramidal in shape. The top of this pyramid is formed by the retractor muscle, which is visible at the dorsal surface of the body running free from the neck region downwards. At the ventral side most structures of the body are covered by the mantle gland. At the dorsal side the gonad, and craniad of it, the liver shines through; the gizzard 
is visible at the upper right side. In the neck region the two tentacles are visible with, in most specimens, the penial structures and seminal groove. The wings and cephalic lobe, with ventral to these the posterior footlobe, with mouth and lips, constitute the most anterior body parts. The colour of the specimen is of importance when comparing some of the developmental stages. The adults are in general darker than the juveniles. In full-grown specimens the body is dark and the wings are lighter. The lips around the mouth, the adjacent part of the posterior footlobe, and the neck region are reddish brown. In some specimens pronounced dark lips contrast with the rest of this region. The mantle is transparent except for the mantle gland. The body is enveloped by an integument showing a metallic irrisation. Through this integument the green colour of the liver, the brown colour of the gonad and the reddish colour of the gizzard are visible. For the development of the shell one is referred to my previous papers (van der Spoel, 1969, 1973).

The male phase develops gradually from the juvenile specimens. All organs show full development, and reach their final size so that they need no description except for the sexual organs. For a description of the non-sexual structures one is referred to van der Spoel (1967). Most typical for males is the presence of a penis at the dorsal side in the neck region; this organ starts to develop in the beginning of the male phase but it may be present in the hermaphroditic and female phase as well (van der Spoel, 1973). The accessory sexual gland is active in the male phase but it shows not its maximal development. The gonoduct is completely present. The receptaculum and bursa seminis usually both contain sperm.

The gonad (pl. I fig. B) in the male phase is characterized by the follicle structure. In the centre of the gonad a lumen connected with the gonoduct is found, ciliated epithelium lines this lumen. The walls of the follicles run from this central lumen towards the periphery of the gonad. In very young gonads the follicle walls are not yet completely formed, in these animals the cells are chiefly spermatogonium cells and primary spermatocytes, homogeneously distributed. When the follicles have developed germinating cells, spermatogonium cells, primary- and secondary spermatocytes, spermatids and sperm are found in their lumen. The follicle walls, in particular the outer gonad wall, are rather thick and composed of connective tissue and germinating cells. A small number of oogonia arranged around the central lumen is found in most gonads of males. The number of oogonia increases when the male phase proceeds. Thus in gonads of males nearly always other cell types than only sperm are found. On the other hand, presence of sperm does not implicate that the specimen is in the male phase, since in all hermaphrodites and in most females sperm is present as well.

In pl. II fig. A histological cross-sections of a male specimen are given; the figures of these sections correspond with those given with the different planes in text-fig. 2. From pl. II fig. B the position of the different organs becomes clear and comparison with the structures in the female specimens in fig. $\mathrm{C}$ is possible.

\section{The female stage}

The differences in external morphology between specimens in the female and the male phase are small. In the females the accessory sexual gland, cranial to the gizzard, is usually larger and more swollen, while the penis is frequently absent. Sometimes it is seen that the surface of the gonad wall in females is a little more bulbous than it is in males.

Anatomical differences between the sexual phases are more clear than morphological ones, as can be concluded from the histological cross-sections of a female from pl. II fig. $C$ and those of the male specimen. The penis is absent; there are, however, also female specimens in which a degenerated penis or even a fully developed male copulatory organ is found. When the penis is absent no trace of it can be recognized in the tissues of the neck region. The seminal groove degenerates likewise. The accessory sexual gland reaches its maximum development during the female phase. As discussed previously (van der Spoel, 1973) it is not completely clear which of the three lobes in the accessory gland contributes to this enlarged activity. The three lobes G1, G2 and G3 are morphologically in a functional stage during the male phase and it is probably only an enlarged activity of $\mathrm{G} 2$ which does increase the total activity of the gland. As to this phenomenon one should be very careful in drawing conclusions, however, since physiological features are studied with histological techniques.

The receptaculum seminis, forming an appendix to the accessory gland, is usually completely 
filled with allosperm during most of the female phase. This allosperm is characterized by its permanent wave structure (van der Spoel, 1967).

The gonad (pl. I fig. C) is very typical in females as it contains the large eggs in different stages of development. The female cells in the gonad are the oogonia, the primary and secondary oocytes, and the ova. The oogonia develop from the germinal cells originally forming the walls of the follicles. It are especially the germinal cells at the top of the follicle walls near the central gonad lumen, that develop into female sexual cells. The oogonia develop into the primary oocytes which grow from a small into a larger stage. The primary oocytes are arranged in pairs. The largest oocytes are found nearest to the peripheral wall of the gonad. The secondary oocytes are larger than the largest primary oocytes; they are found on top of the rows of primary oocytes. The ripe ova are found pressed against the inner side of the gonad wall.

The description of the different sexual phases is given to make comparison possible with the aberrant stage and the sterile primary specimen which forms the aberrant stage through strobilation.

\section{Developing aberrant stage and strobilation}

The aberrant stage is formed by a normal primary specimen through a kind of caudad budding. With "normal primary specimens" animals are indicated with all organs, except the sexual organs, in normal development. Some specimens were found by the Ocean Acre Program in which the primary specimen was still attached to its strobila (fig. 3). One of these specimens was sectioned for histological studies after decalcification. These series of sections made it possible to detect the characters of both parts and their connection during the process of strobilation.

The primary specimen is not attached to the shell; though it is provided with a columellar muscle it is only attached by connective tissue to the aberrant stage situated posterior to it (fig. 4). Supposingly the primary specimen was originally fixed to its shell by the columellar muscle. The aberrant specimen is fixed to the shell with its own columellar muscle. In all probability the connection of aberrant specimen and shell is a secondary connection. The columellar muscle of the bud starts to develop in the ventral lip between the wings and grows out posteriad. From the

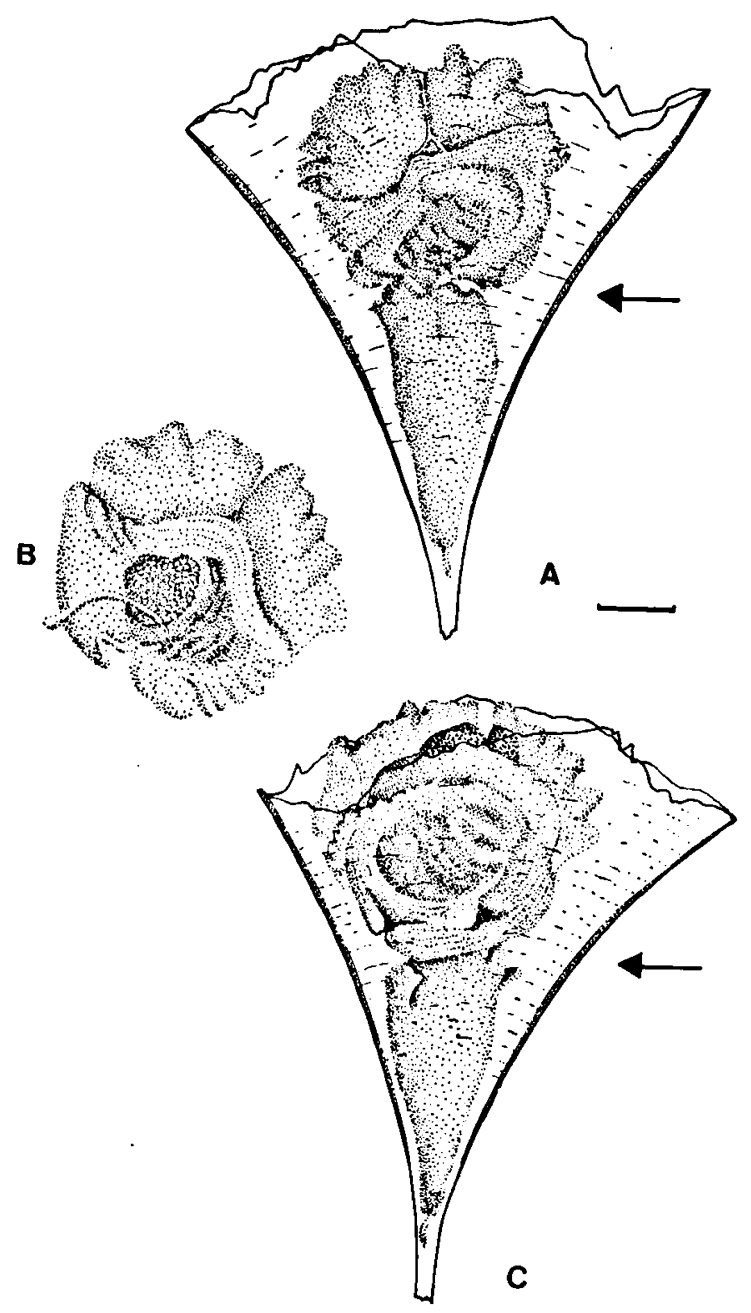

Fig. 3. Clio pyramidata forma lanceolata during the process of strobilation. $A$, the entire animal seen with the shell in dorsal view; $B$, the soft parts of the primary specimen in caudal view; $C$, the entire anım.l with the shell in ventral view. Scale $1 \mathrm{~mm}$; arrow indicates place of strobilation.

same centre in the lip, the muscles of the body wall and wings start already to develop during the strobilation. Near the distal top of the columellar muscle a shield of glandular epithelial cells develops (fig. 5). This shield is pressed against the posterior side of the shell's top and secretes a web-like mucus layer encircling the shell (figs. 5-6). The presence of these epithelial cells and the ring of mucus show that the muscle is in a process of attaching. Comparable structures near the top of the columellar muscle are never found in normal, adult or juvenile Clio specimens.

The transition between the primary specimen and the strobila is given in fig. 4. A gonad 


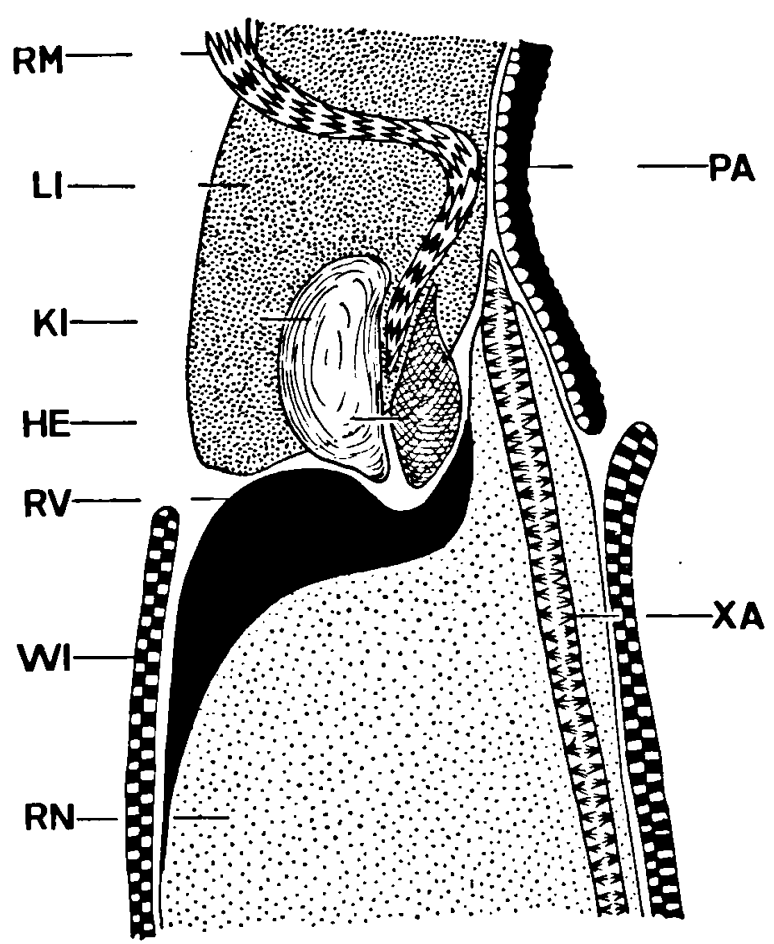

Fig. 4. Diagram of the link between the aberrant specimen (lower part) and the primary specimen (top part) (for abbreviations see page 203).

is completely absent in the primary specimen and the aberrant stage takes its place (fig. 2 F-G, pl. II fig. D). The anterior top of the aberrant specimen is surrounded by the posterior part of the primary specimen. In the period, just before

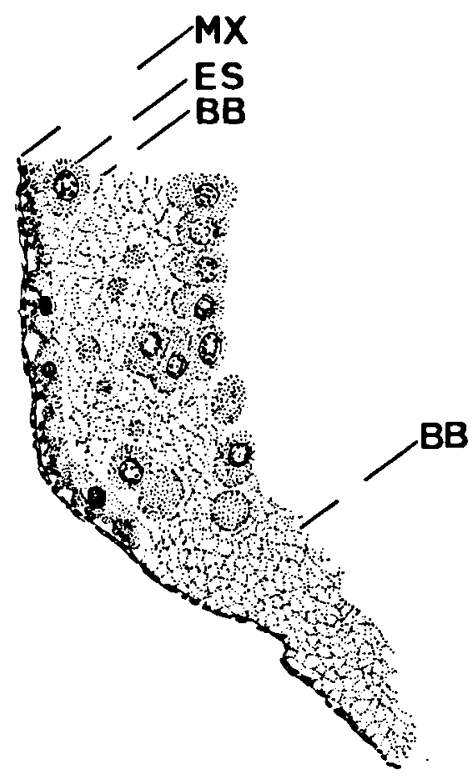

Fig. 5. The epithelial shield around the top of the retractor muscle in cross section after a H.E. stained slide (for abbreviations see page 203). the separation, the XA tube of the strobila penetrates in between the pallial gland and the liver where the heart-kidney system is found. Besides the absence of a gonad it is typical that the retractor muscle takes a strange position in the posterior pole of the primary specimen. The slightly degenerated muscle is twisted around the body and it ends posteriorly at the ventral side.

All organs of the primary specimen are of a normal structure, and to judge from the contents of different parts of the alimentary system, normal feeding takes place. The esophagus, gizzard, stomach, and intestine are filled with fragments of diatoms and foraminifera and the liver lumina and liver cells contain secretory substances. The pallial gland and other mantle structures are of the normal type and the glandular cells are in a functional stage. The central nervous system is completely developed and so are the sensory organs. The position and structure of the organs are shown in pl. II fig. D.

Absent in the primary specimen is, however, the gonoduct of which no trace could be found. The accessory sexual gland and the seminal groove are represented by small concentrations of interstitial cells only. These organs are thus developing for the first time or they have disappeared first completely before regenerating again. The same holds good for the penis which is represented by not more than a tube of interstitial cells.

The organization of the primary specimens resembles the situation in juvenile animals, though

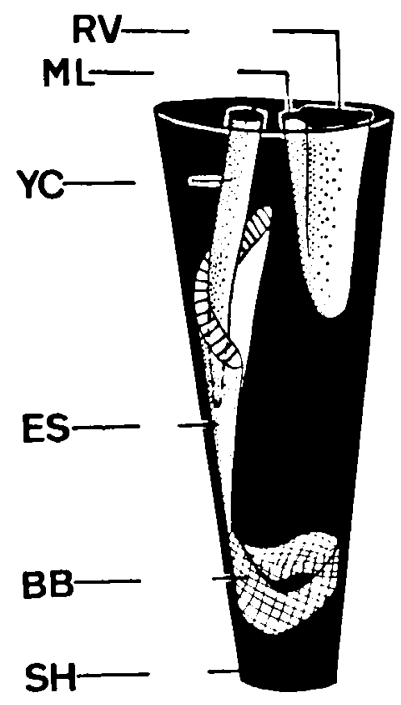

Fig. 6. The new attachment of the columellar muscle of the aberrant specimen in the top of the shell (for abbreviations see page 203). 
they are no real juveniles. Differences with juvenile specimens are formed by the relatively larger size of most organs and their complete development, and by the absence of a concentration of germinating cells at the lateral side of the liver which in juveniles gives later rise to the gonad.

Summarizing, the primary specimen is an asexual specimen connected by connective tissue with the aberrant stage of which the XA tube penetrates the primary specimen.

\section{The aberrant stage}

The body morphology of the aberrant stage differs strongly from that in normal specimens (cf. p. 206). Most striking is the colour of the aberrants which is whitish in preserved specimens and orange-red in live ones, a colour which clearly contrasts with those of normal specimens. During the process of strobilation the dark primary specimen can be easily distinguished from the lighter strobila posterior to it. The size of the aberrants is variable and differs also in the different formae. The smallest body length of the aberrants is found in Clio pyramidata forma lanceolata (Lesueur, 1813); it varies between 3 and $8 \mathrm{~mm}$. This wide size range is due to the growth of aberrants during their differentiation. In the forma sulcata (Pfeffer, 1879) the body length of the aberrants varies between 8 and 16 $\mathrm{mm}$, while it is also larger, up to $15 \mathrm{~mm}$, in the forma antarctica Dall, 1908. Aberrants are also found in the forma pyramidata but never in the other formae of the species. The formae excisa van der Spoel, 1963 and martensii (Pfeffer, 1880) are only rarely found, but in the forma convexa (Boas, 1886), though frequently found, still no aberrants are known.

The wings of the aberrant stage are attached to the most posterior top of the specimen, and they are curled around the body when the animal is found in its shell. Though this is the normal situation, sometimes specimens are found of which the shell has disappeared by accident. In these shell-less aberrants the wings usually are expanded (fig. 7, C). At the ventral side between the attachment of the wings three vaults are found, two of which may develop into the lips, the largest one develops into the posterior footlobe. In the body section under the attachment of the foot and wings, the organs which resemble normal organs in full-grown specimens are found. In the centre of this part of the body a tube

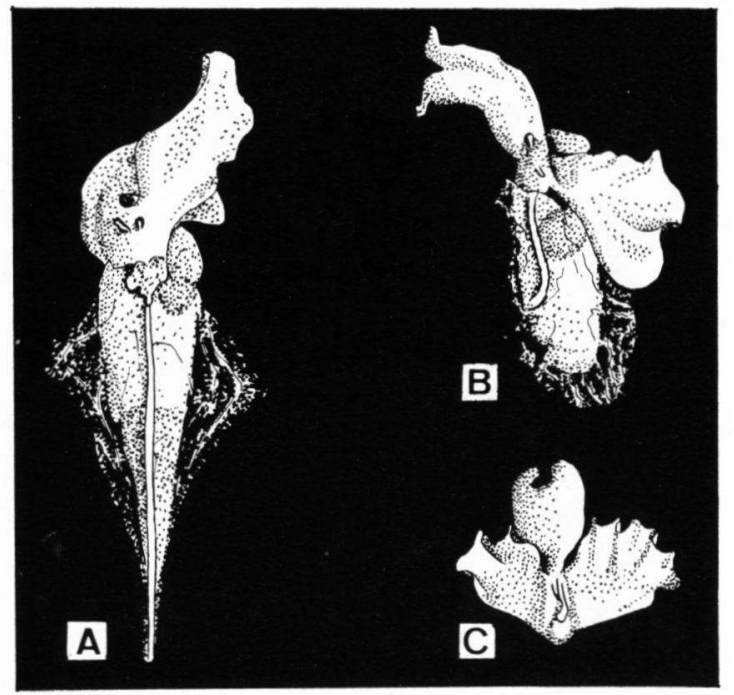

Fig. 7. Three specimens which were collected without shells. The plankton sample concerned was directly frozen after it was caught so that no shells could be destroyed by the preservative. Specimen $A$ is a normal adult animal of which the shell is lost, since it was broken. Specimen B is a primary animal after strobilation which may have left its shell. Specimen $C$ is an aberrant specimen.

(XB) is found which can be considered the germ of the alimentary system. Around the tube XB the muscles of a developing gizzard and the cells of the central nervous system are found (fig. 8). The anus and mouth are found in a very strange position; when taking the position of the tube $\mathrm{XB}$ as normal, the mouth is found at the dorsal side of the body at a distance of $1 / 3$ of the body length anterior to the end of the columellar muscle. The anus is found at the ventral side but completely posteriad. This organization is almost worm-like. The aberrant specimen is, however, not a parasite laying in the shell top of an infected specimen. The cell types of the gizzard muscles, the structures of the central nervous system and the cells found in the wings are typically the same as in Clio pyramidata. The tube $\mathrm{XC}$ (fig. 8) could not be homologized with a structure similar to an organ in normal specimens; as a hypothesis this tube can be regarded as the heart-kidney system.

The top of the body shows no structures resembling those in normal specimens. Though the integument is clearly that of a thecosomatous animal, the whole anterior glove-shaped part has to be considered a structure unparalleled in other pteropods. The major part of the top section is filled with reserve tissue. Only the long XA tube 


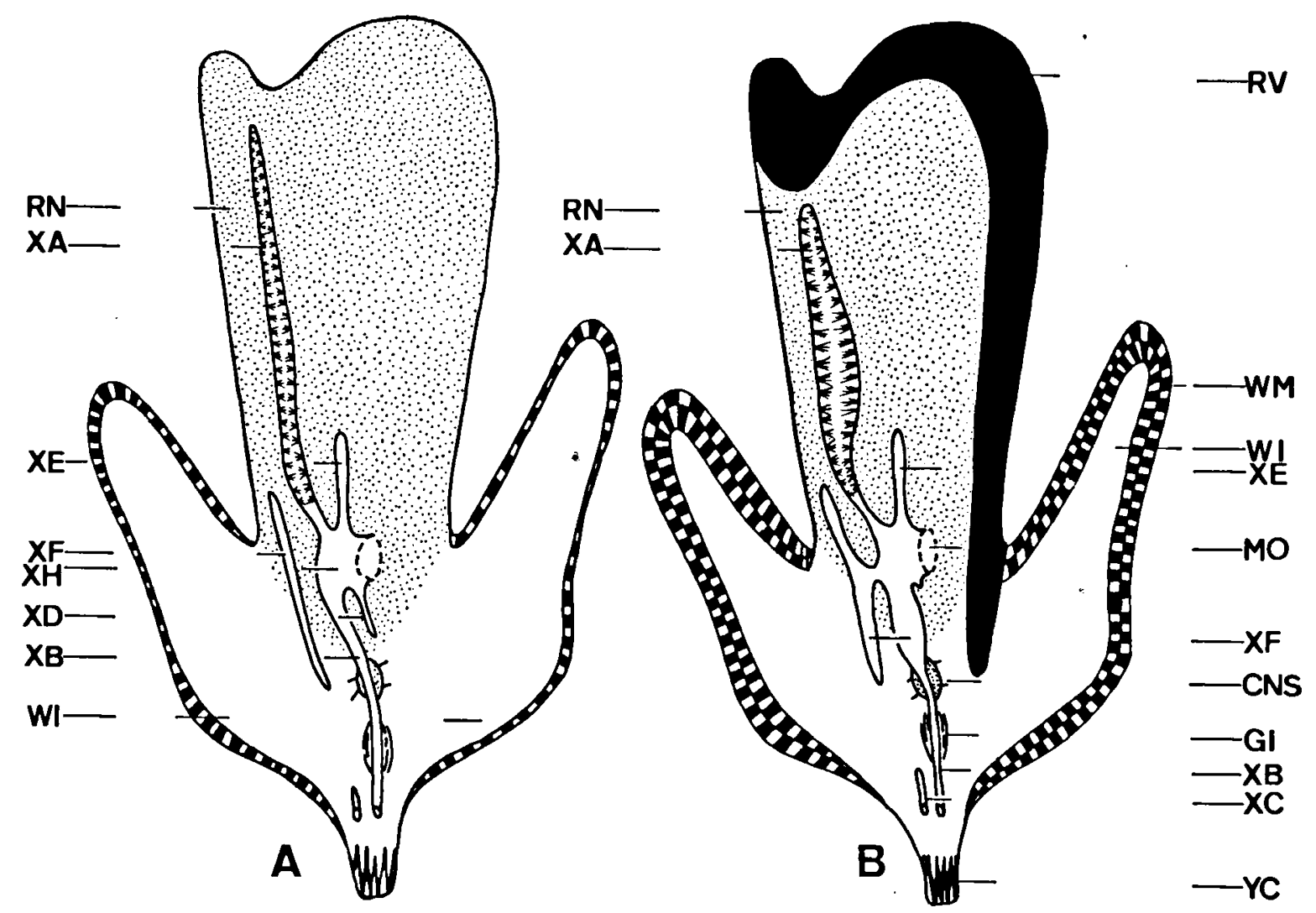

Fig. 8. Diagram of the development of an aberrant specimen. A, young aberrant; B, older aberrant stage with developing liver and wing muscles (for abbreviations see page 203).

differs from the reserve tissue. The XA tube is of gonadial structure (pl. I fig. D). This tube is surrounded by a very thin connective tissue wall. Attached to this wall small clusters of germinal cells are found, which are grouped in the form of unilayered epithelial folds. This epithelium can not be traced as a continuous layer inside the tube wall. A great difference between the XA tube and the normal gonad consists in this difference in wall structure, being thick in gonads and extremely thin in XA tubes. The cell types most frequently found in the XA tube are sperm cells arranged in bundles perpendicular to the tube wall. The sperm tails in these bundles show as a rule the permanent wave structure. This permanent wave structure occurs probably as the result of storage in the lumina over a longer period. Along the tube wall some cells without nuclei are found; the position of these "nuclei lacking cells" with regard to the sperm concentrations does suggest that they function as sustaining cells of Sertoli. In addition to sperm, also spermatogonium cells, primary spermatocytes and spermatids are found and the germinating cells already mentioned. Secondary spermatocytes rarely occur. Absent are all celltypes taking part in the oogenesis. In nearly all normal gonads, as mentioned, cells participating in the oogenesis are found. The second principle difference between XA tubes and gonads is thus found in the absence of female products in the former. The XA tube neither resembles the gonad in juveniles (pl. I fig. A), since in juveniles the gonad is in a pre-male stage showing no sperm but almost only germinating cells or primary spermatocytes, while the XA tube shows clearly spermatogenesis. In all probability this spermatogenesis points to a rapid development of the aberrant into a functional male. When development is suppressed the gonad usually contains only one type of cells (van der Spoel, $1967: 168$ ). The specimen executing strobilation can not have been a male since the primary specimen develops a penis, and it is not a juvenile either; as a consequence it can not have been anything else than a female. Probably the aberrant starts a protandric cycle while the primary specimen, giv- 
ing rise to this strobila, stands in between two sexual cycles. For a more complete histological description of this stage one is referred to previous papers (van der Spoel, 1962, 1963, 1967).

\section{Growing aberrant stage}

The animals developing from an aberrant stage into a normal specimen are called growing aberrants.

During the growing phase, first a transformation of the tubes occurs in the aberrant, and in. the anterior top a kind of liver tissue starts to develop. In a next stage the appendages of the body change their position and start to grow.

Amongst the Ocean Acre Program collected specimens showing strobilation, one of the two strobilae, still attached to the primary specimen, had the liver already developing in the most cranial part of the strobila. In other samples with aberrants, sometimes different developments of this liver tissue are found. Growth of the aberrants thus may start at different moments and aberrants attached to the primary specimens may show already evidence of development, especially in the liver tissue.

The number of growing aberrants which were nearly transformed into normal animals, seen by me, was two; none of these specimens could be studied histologically. Histological data discussed below are all from aberrants in their first development.

In my previous publication (van der Spoel, 1967: 192) the histology of growing aberrants is discussed. This description was correct except for one point. The growing aberrant stage indicated with "TA" was considered the stage occurring before and after the real aberrant stage, the latter indicated with "RA". As it proved that the aberrant develops by strobilation, the growing aberrant ("TA") can only develop out of the aberrant.

In all aberrants wing muscles are present but their number and size increases dinstinctly during development. This development results in the occurrence of two clearly separate crossing layers (fig. 9). At the same time most interstitial cells disappear and the lumen in the wings develops. In this lumen the cells with reserve tissue decrease in number and a central wing muscle becomes visible. Along with the development of the muscles in the wings, a muscle layer around

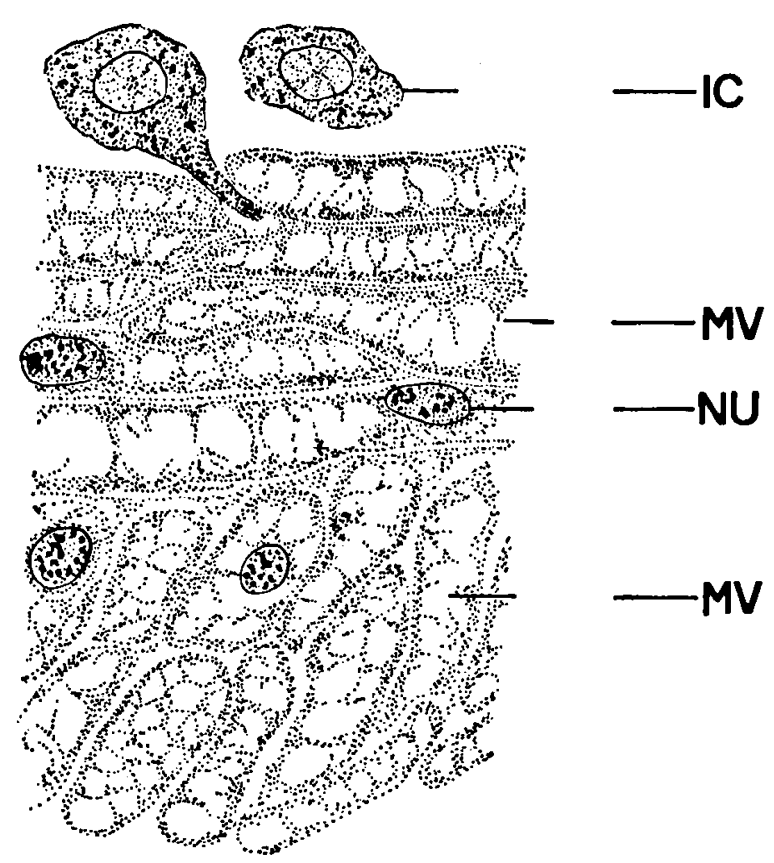

Fig. 9. The two muscle layers of the wing from a growing aberrant specimen (for abbreviations see page 203).

the posterior body pole originates and the columellar muscle becomes somewhat longer. The part of the body below the upper attachment of the wings becomes more isolated. The quantity of reserve cells decreases and the size of the anterior body parts becomes relatively smaller. The central nervous system develops further, the nerve cells take a more crowded position, and the ganglia get more their final shape.

The tissue with reserve cells becomes more differentiated, in some specimens this differentiation takes place before the occurrence of the young liver tissue. The reserve tissue is normally of a follicle structure composed by one cell type. In the growing aberrant three types of cells are found in the follicles (cf. van der Spoel, 1967: 185). It is not clear how the development of the reserve tissue proceods and which development the three different cell types follow.

From a special centre near the anterior top of the XA tube, the liver tissue starts to develop and it grows out posteriorly towards the plane in which the central nervous system is found. This tissue is named "young liver" tissue, since it resembles most digestive cells (fig. 10), but it is not sure that the liver really develops from these cells. It is not excluded that special differentiation of the reserve tissue may result in real liver 


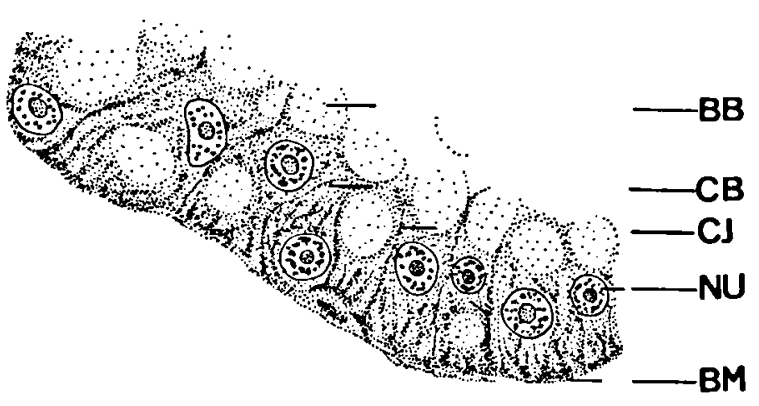

Fig. 10. Row of young liver cells from a developing aberrant stage (for abbreviations, see page 203).

tissue. The lumina left in between the "young liver" cells, however, resemble almost exactly the structures found in the liver of adults. In the system of tubes the first change visible is the occurrence of an open connection between the tubes $\mathrm{XF}$ and $\mathrm{XH}$, and decrease in length of the tube XD.

An important change in the anatomy of the growing aberrant is found in the tube XA. The tube length decreases to make room for the increasing quantity of young liver cells, which form at the anterior side of this tube as well. The width of the tube increases, however, strongly. The more developed the aberrant is, the larger the quantity of male sexual products in the tube XA.

The external morphology of the growing aberrant is variable. After an increase of the foot and wing parts, these appendages shift to their normal anterior position. The mantle occurs later, it develops from two folds arising from the lateral sides of the body. The number of growing aberrants at my disposal was too small to give a more detailed picture of this development.

\section{DISCUSSION}

The development of the aberrants can be considered budding or strobilation. Budding is the asexual reproduction in which a new individual arises as an outgrowth, the bud, on an older specimen. Strobilation is the transverse fission of a specimen by which new specimens arise; these specimens either grow out to sexual specimens (in Coelenterata) or they are more or less incomplete organisms transporting sexual products only (in Annelida and Plathelminthes). The formation of aberrant specimens in Clio resembles strobilation as found among the worms more than budding. This means that, only in the species
Clio pyramidata, a phenomenon is found indicating an affinity to the worms or a convergence in its evolution to this group. As the Thecosomata are rather specialized animals, not at all orginal in morphology, it is most plausible to consider the strobilation in the worms and molluscs the result of convergent development. But phylogenetic relations between molluscs and worms exist, so it is possible that the strobilation represents an additional relation between these two groups, supporting those found in ontogeny and anatomy.

The organization of the aberrant stage is also typically worm-like by its straight alimentary system ending anteriorly into the mouth and posteriorly into the anus.

There is no explanation for the fact that Clio pyramidata is the only species in the Thecosomata showing strobilation. That strobilation has a special selective advantage for this species, may be explained by the great diversity of environments occupied by the species, which has a wider distribution than that of any other pteropod.

Still puzzling is the further development of the primary specimen after the formation of the aberrant specimen by strobilation. When the primary specimen swims out of the shell, from which it detaches completely during strobilation, it starts the life of a naked pteropod. Though sometimes shell-less specimens of Clio pyramidata are found among freshly preserved samples one can never be sure that their occurrence is natural. There are, however, three types of shell-less specimens: there are naked aberrants (fig. 7, C) which lost the shell and normal specimens which lost their shell. Among these "normal naked ones", specimens occur with a straight columellar muscle and well-developed gonad (fig. 7, A) together with specimens showing a degenerated columellar muscle and no gonad at all (fig. 7, B). The latter specimens are in all probability specimens which had executed strobilation and left their shell, while the former ones are normal animals which lost the shell by accident. This gives not yet an indication concerning the development of the primary specimens. Since these animals show developmental processes in their sexual system it is not expected that these specimens are doomed to die directly. Consequently it is assumed that the naked Clio pyramidata animals will form a secondary shell. Otherwise they will persist as naked specimens in the plankton, for which no supporting evidence is available at the moment. Secondary shell formation 
is not impossible, but in one population of Clio pyramidata always only one type of shell is found. It is difficult, if not impossible, to understand how primary and secondary shell can be morphologically similar, since it is hard to explain how e.g. an embryonic shell can be formed in a secondary shell. At the moment it are the naked specimens without gonad and with developing accessory sexual organs which constitute the most "developed" stage of the primary specimens after strobilation found by me.

The number of aberrant specimens shows a tendency to be greater in samples in which two formae of Clio pyramidata occur mixed together. The sample from $47^{\circ} 31^{\prime} \mathrm{N} 6^{\circ} 59^{\prime} \mathrm{W}$ containing over 50 aberrant specimens of the forma lanceolata, consisted of a mixture of specimens of the formae lanceolata and pyramidata. Clio pyramidata forma lanceolata reaches at approximately $47^{\circ} \mathrm{N}$ its northernmost distributional border (van der Spoel, 1967), as is also shown by the mixed occurrence of formae. This may indicate that stro- bilation occurs when environmental conditions become critical. For sake of completeness it should be mentioned that all possible intermediates between the two formae are found in the sample mentioned.

When it is accepted that reproduction occurs more frequently during the beginning of optimal conditions, it can be concluded that during the period before the reproductive optimum, conditions are less favourable. Since aberrants are most frequent before the reproductive period, it may be the less favourable conditions which induce the process of strobilation (cf. fig. 1). The first protandric hermaphroditic sexual cycle may be followed by a secondary protandric cycle, by a gradual change of the female phase into the second male phase (van der Spoel, 1973). The specimen giving rise to the strobila may be also a stage in between two protandric cycles, but this is another type of cycle change than the gradual, and it results also in the separation of a second animal which can complete its own sexual cycle.

\section{LITERATURE}

SPOEL, S. VAN DER, 1962. Aberrant forms of the genus Clio Linnaeus, 1767, with a review of the genus Proclio Hubendick, 1951. Beaufortia, 9 (107) : 173200 , figs. $1-10$, photo's $1-2$, diagr. $1-2$.

-, 1963. A new forma of the species Clio pyramidata Linnaeus, 1767, and a new resting stage of Clio pyramidata forma sulcata (Pfeffer, 1879) (Gastropoda, Pteropoda). Beaufortia, 10 (114) : 19-28, figs. 1-5.

,- 1967 . Euthecosomata, a group with remarkable developmental stages : 1-375, figs. 1-366 (Noorduyn \&
Zn., Gorinchem).

-, 1969. The shell of Clio pyramidata L., 1767, forma lanceolata (Lesueur, 1813) and forma convexa (Boas, 1886) (Gastropoda, Pteropoda). Vidensk. Meddr. dansk naturh. Foren., 132 : 95-114, figs. 1-12.

,- 1973 . Growth, reproduction and vertical migration in Clio pyramidata Linnaeus, 1767 forma lanceolata (Lesueur, 1813) with notes on some other Cavoliniidae (Mollusca, Pteropoda). Beaufortia, 21 (281) : 117 134, figs. $1-9$. 


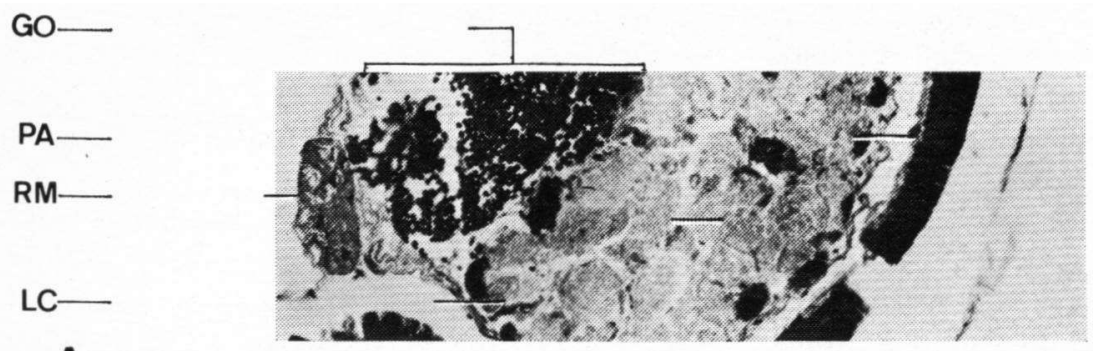

A
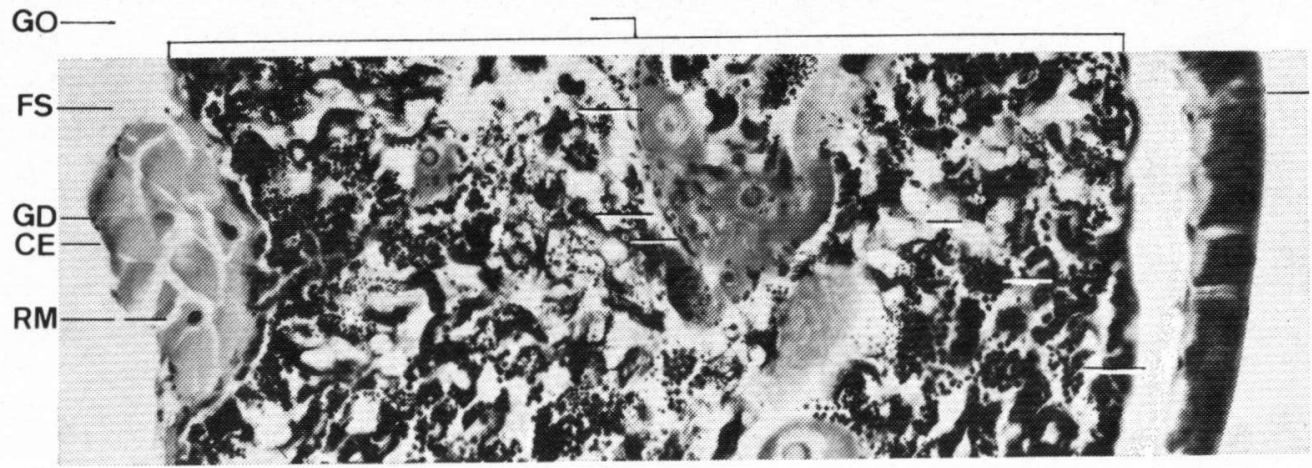

B
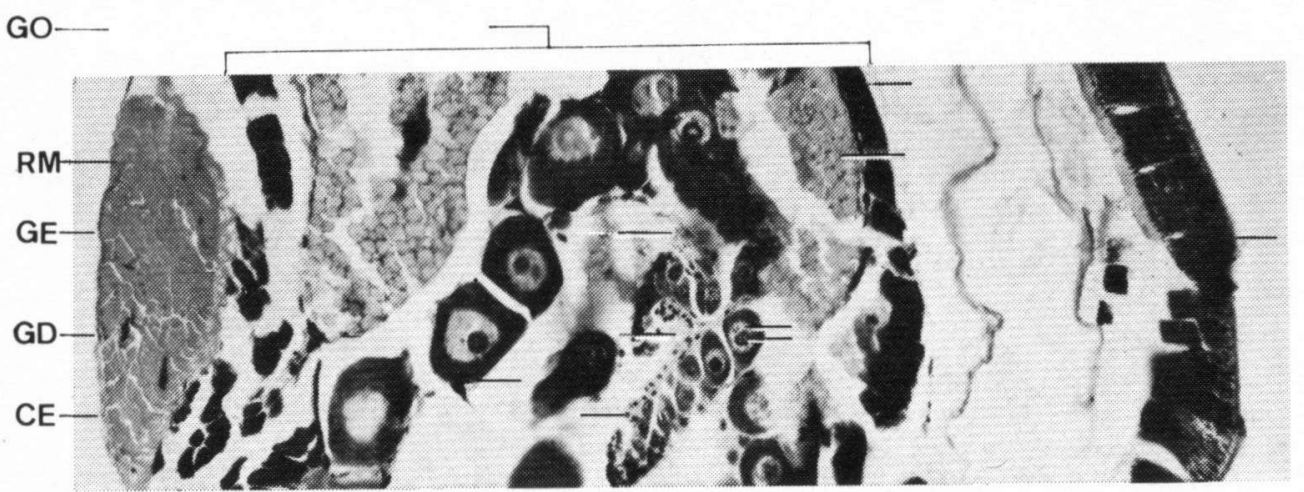

- GE

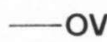

C
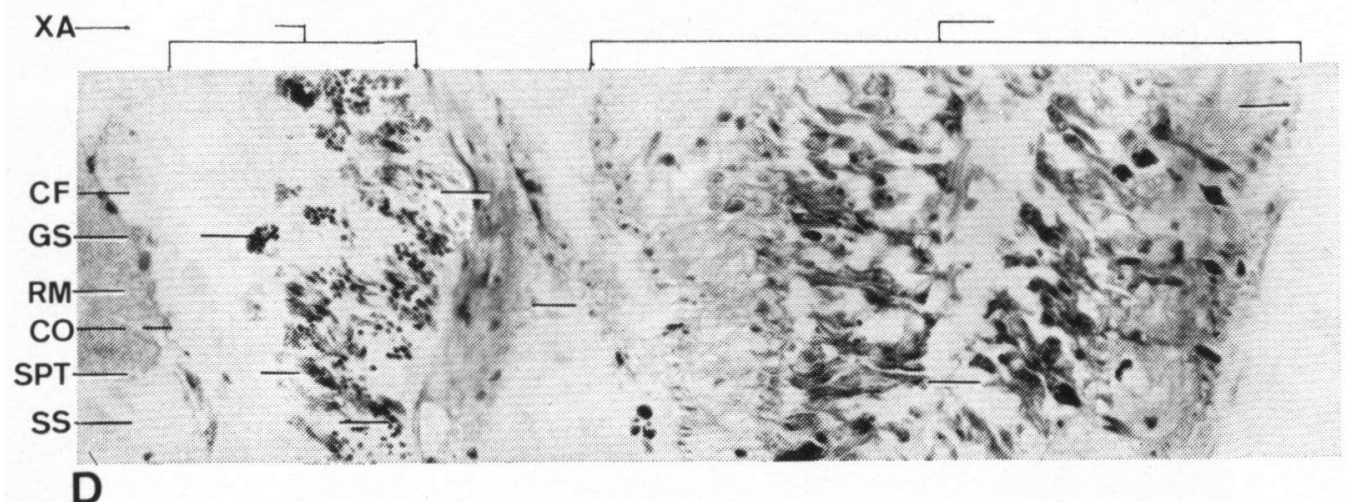

Plate I. Photomicrographs of H.E. stained cross-sections through gonads in different stages of development; A, from a juvenile; $B$, from a male; $C$, from a female gonad; $D$, through the XA tube of an aberrant specimen (for abbreviations see page 203). 


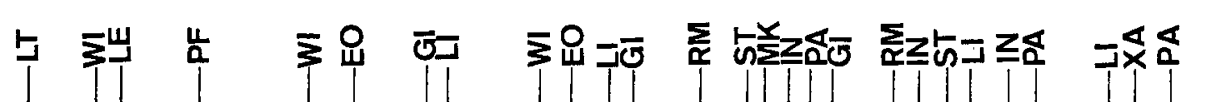

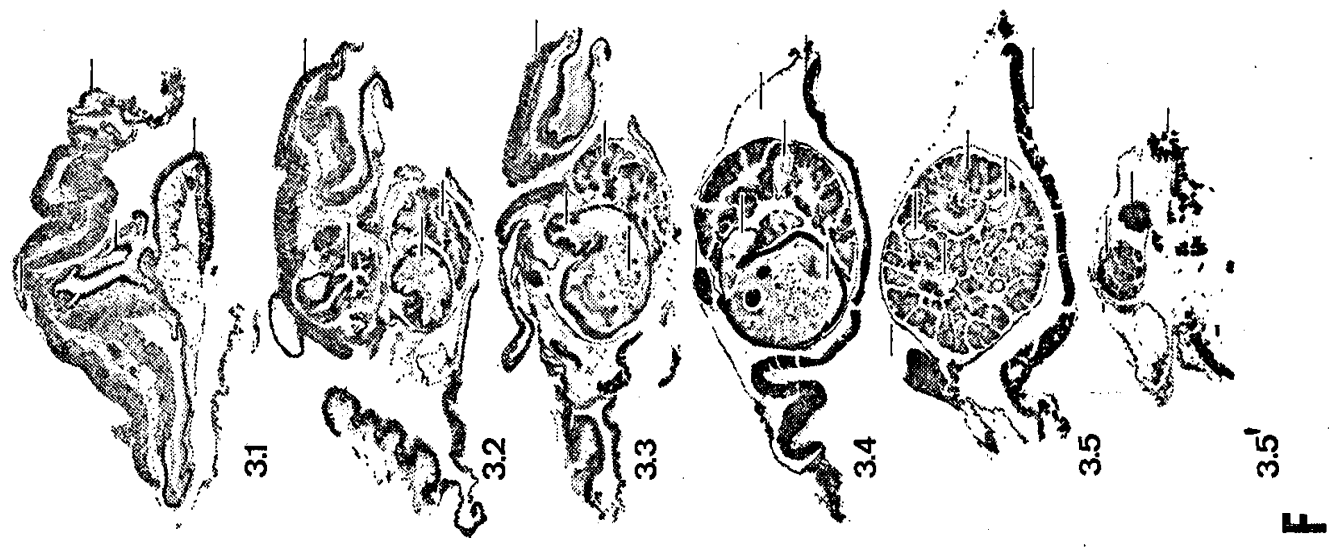

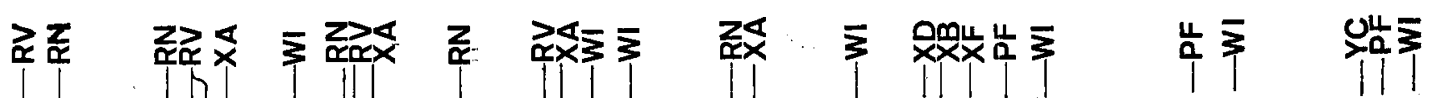

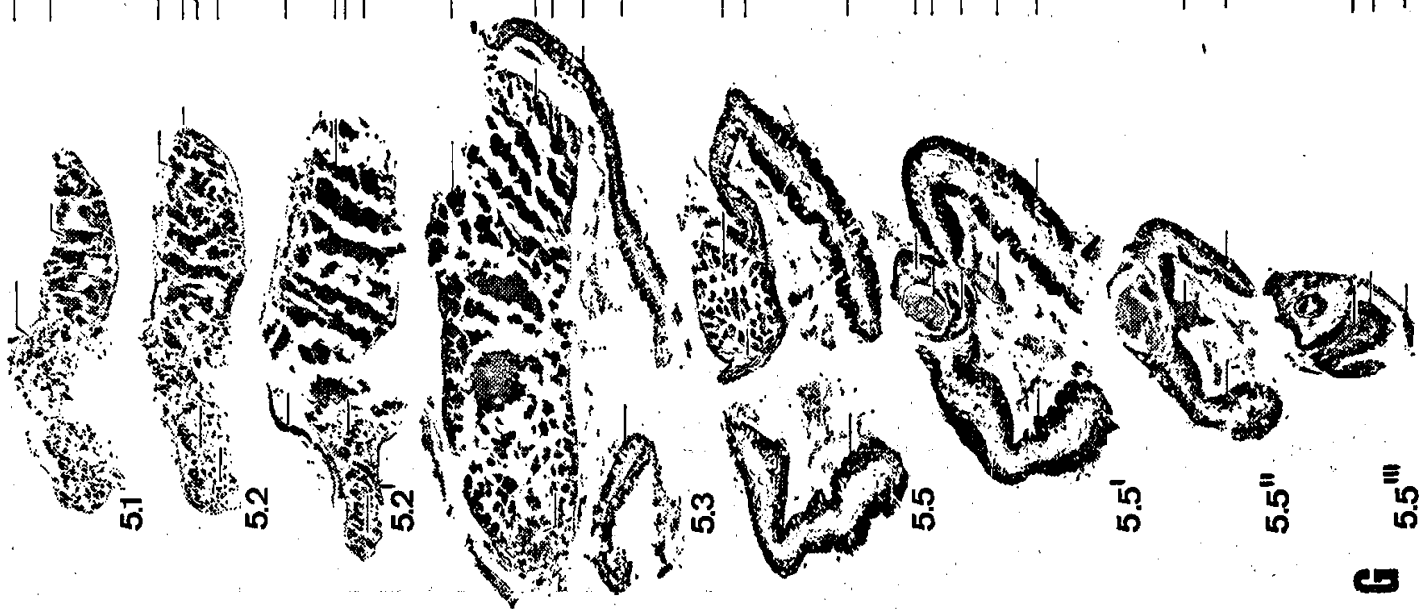

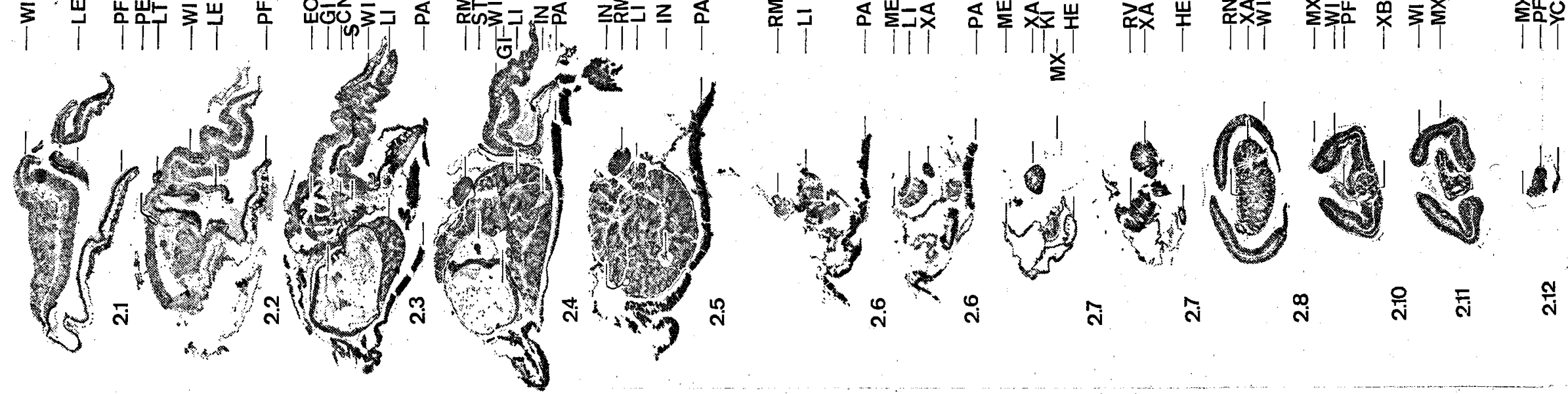
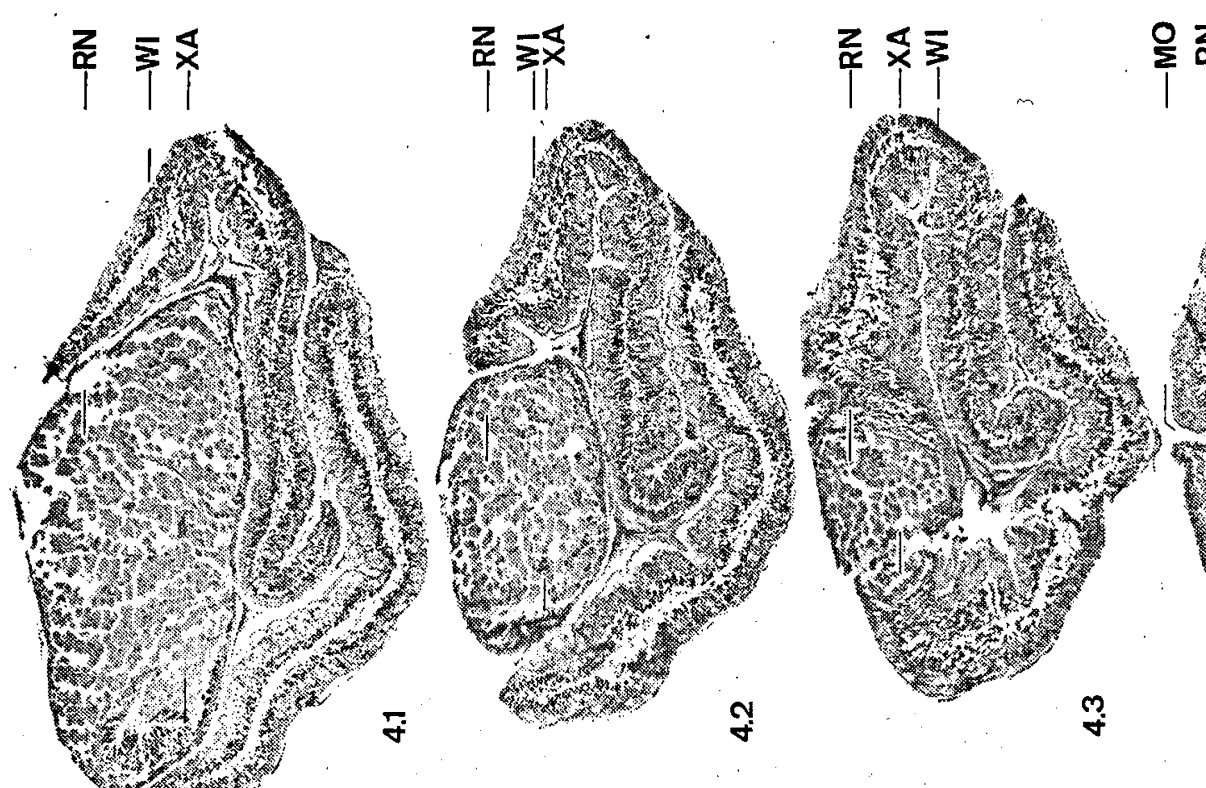

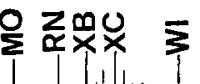

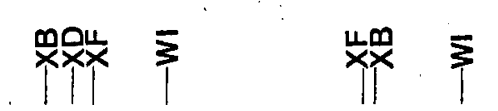
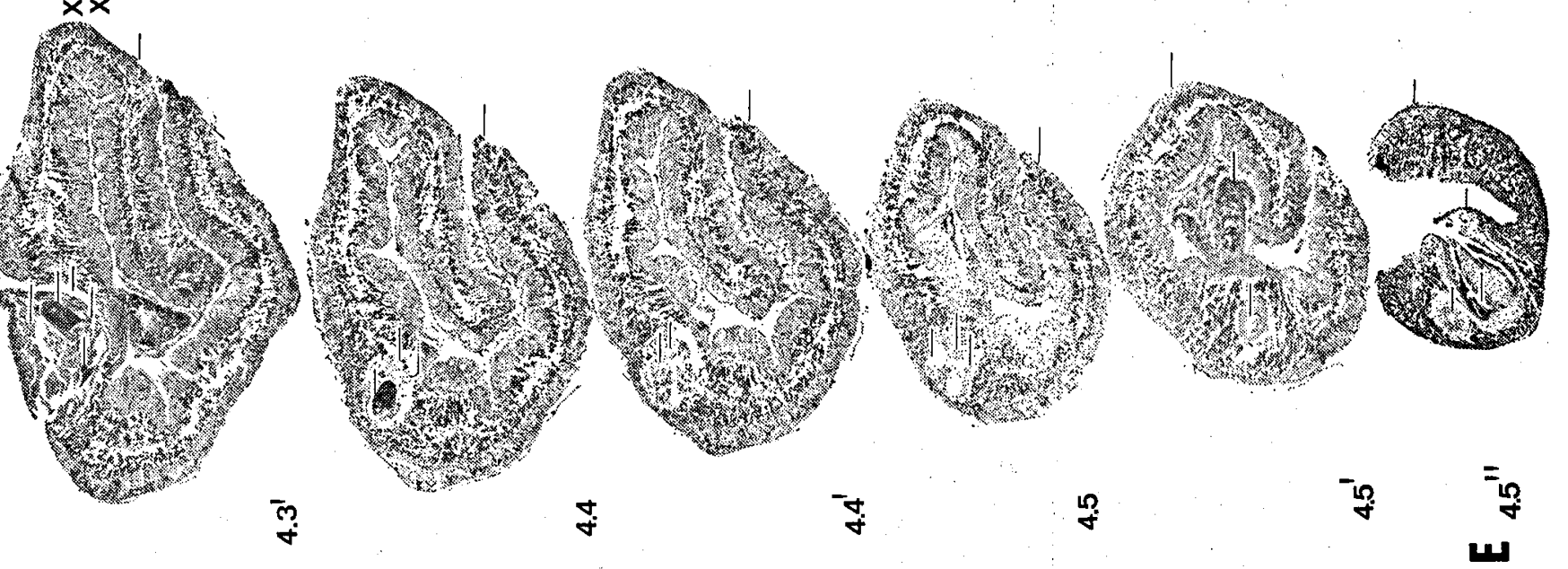

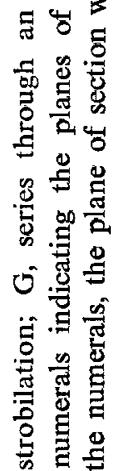

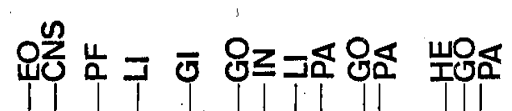

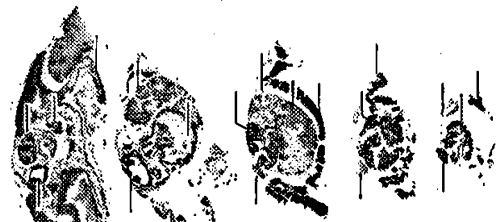

ชุ

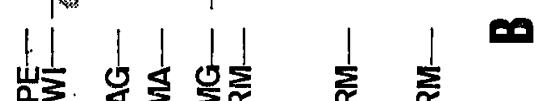

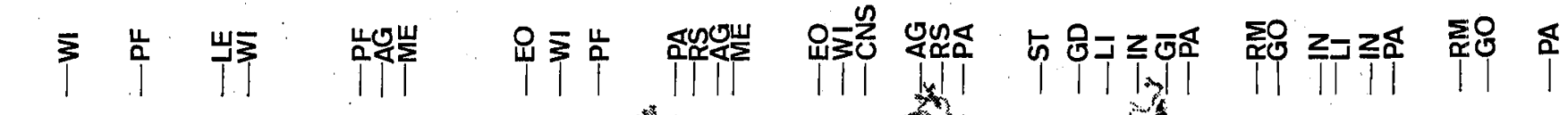

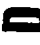

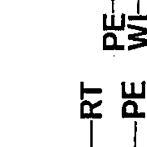

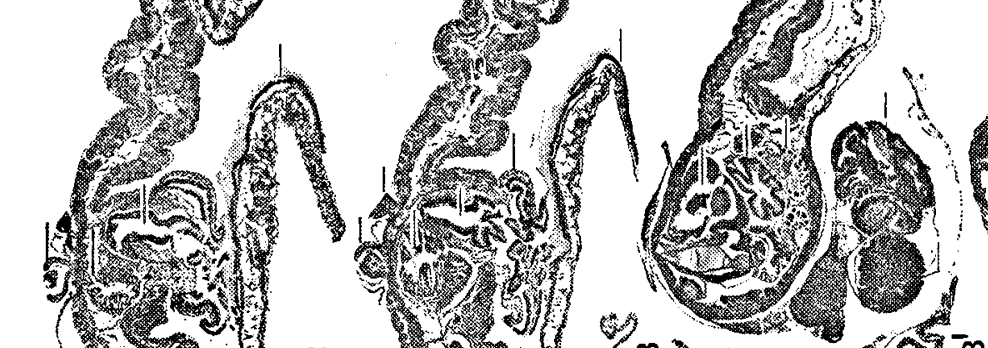
W Ny 


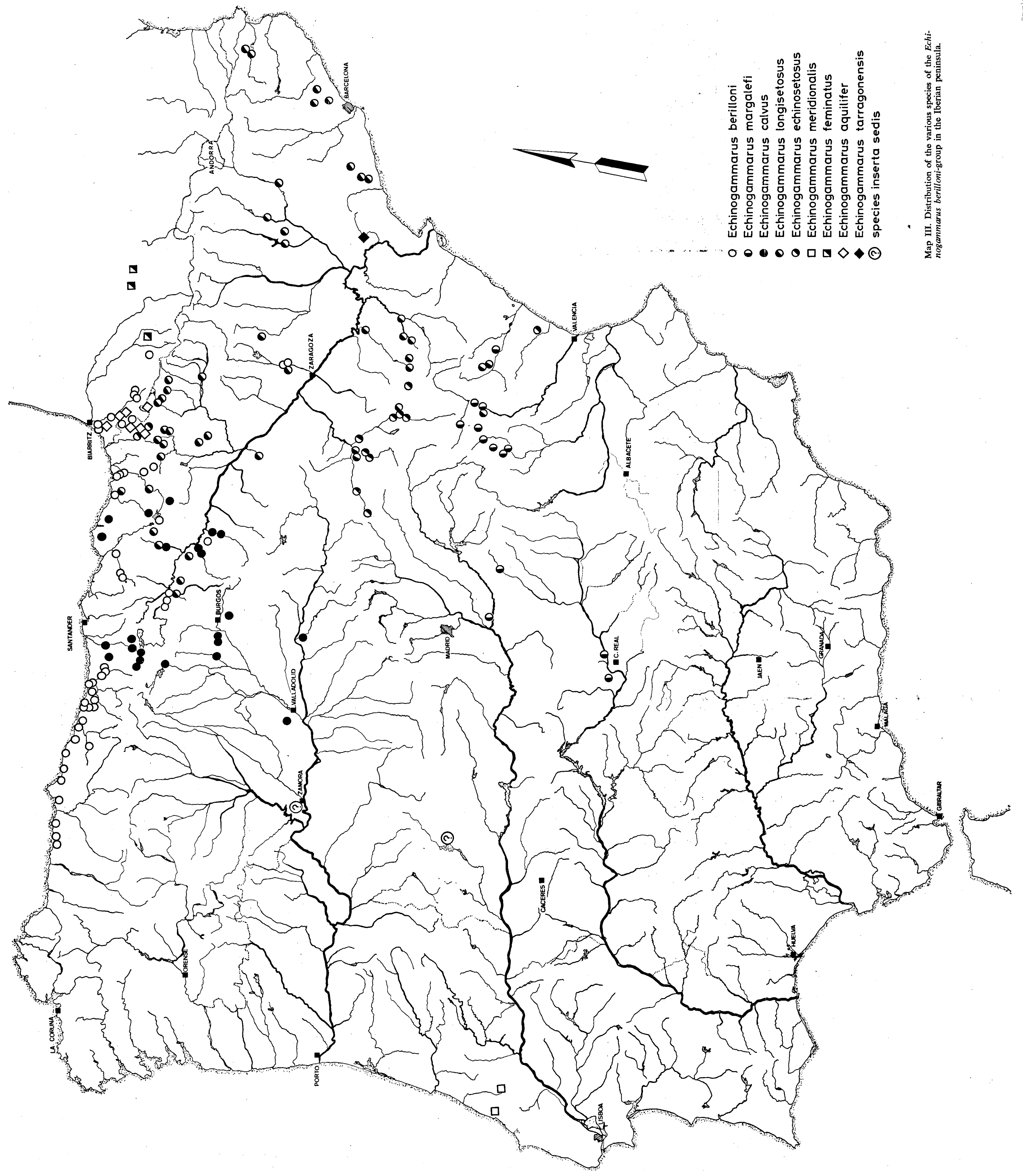

